\title{
Risk Analysis: A Methodology Applicable to the
}

\section{Building Inspection}

Mauricio Noya ${ }^{1}$, Ana Lucia Torres Seroa da Motta $^{1}$, Mariângela Moura ${ }^{1}$, Rafael Carvalho de Souza ${ }^{1}$ and Bruno Barzellay $^{2}$

1. Programa de Pós-graduação em Engenharia Civil, Universidade Federal Fluminense, Rio de Janeiro 22211-200, Brazil

2. Departamento de Engenharia Civil da Universidade Federal do Rio de Janeiro-Campus Macaé, Rio de Janeiro 22211-200,

Brasil

\begin{abstract}
The lack of care related to maintenance management is directly linked to the absence of plans for maintenance of buildings. Because of that, there is a big incidence of building accidents caused by the negligence of managers and the lack of investment. The research has shown that, although building inspection is a consolidated building maintenance tool, managers do not prepare their building maintenance plan, nor use building inspection as a tool, leading the buildings to the premature obsolescence. The research calls attention to the building inspection technique that can be used to evaluate building maintenance and conservation. It is also a tool for analysis and investment planning based on actions to solve failures and anomalies that might come out during the building inspection. Those failures and anomalies are classified according to their degree of risk, determining the technical priorities of the investment adjustment in the maintenance plan. The paper presents a risk analysis methodology which classifies inspect elements in a building, determining the priority order of services to be executed on a scale from minimum risk (1) to imminent risk (5). The method shows a tool for building inspection, and it serves as a guideline for building maintenance interventions.
\end{abstract}

Key words: Civil engineering, risk analysis, building inspection, building maintenance.

\section{Introduction}

With the shortage of available buildable areas, real estate vertical density in urban centres became inevitable. In addition, with that situation, there are also the deficiencies related to the lack of strategic plans to guide the maintenance and conservation of these buildings.

The buildings, whether commercial or residential, are a vital physical space for the development of various activities performed by man in society. Without such buildings, it would be impossible to accomplish those activities within the minimum technological and safety standards required for them [1]. The huge infrastructure that had been built over the centuries with diversified materials is today mostly made of reinforced concrete structures subject

Corresponding author: Mauricio Noya, M.Sc. architect, research field: civil engineering. to a great variety of weathering, requiring constant maintenance work [2]. When it comes to the manager, maintenance should not be understood only as an action that aims to extend building life span. In fact, it goes much further than that, as it should be the mechanism to operationalize all building components in order to provide the minimum requested performance [3].

In many cases, the absence of a maintenance plan reflects how incipient the culture of conservation and preservation is, especially when it comes to corrective and emergency actions that do not follow a record of intervention services to be performed. The consequences of that can be disastrous. Moreover, improper maintenance, when it is not preceded by adequate inspection, not only contributes to the depreciation of assets, but can also result in rework and unnecessary increased costs. [4]

In most cases, after its construction, the building is 
handed over to the owners, that, in turn, elect a manager who is frequently not a professional in the field, and does not hold any qualification, or even technical capacity to manage a maintenance process, which, in some cases, is highly complex [5].

The lack of technical expertise and the omission related to the proper care of building maintenance compromise the real estate performance over the years, prematurely reducing its service life [6, 7]. Such was the case of some regrettable episodes involving the safety of buildings in various Brazilian states, especially the total collapse of three buildings in downtown Rio de Janeiro, as shown in Fig. 1, as well as a series of building accidents, such as falling façade materials, electrical fires, among others.

To Lessa [8], extending the life of a building means lowering the running costs, as well as the cost of machinery maintenance, fixtures and equipment to obtain greater durability. It should be noted that building inspection should guide all maintenance plan. Technological advances brought along a great variety of new equipment and physical items, requiring managers to keep up with this quest for knowledge and application of new inspection techniques focused on building quality. The inspection should include structures, basements, façades, window frames, walls, marquee, roofs, and consequently, their electrical, plumbing, sanitary, electromechanical, and gas installations, and also fire protection and escape installation, as well as the construction of slope retention, among other compartments. The inspection must be performed by professionals or qualified companies [3].

Aiming to guide the qualified personnel in the practice of building inspection, the article presents a risk analysis methodology for the realization of building inspection. Based on the Mosler method, it classifies the risk of inspected elements determining the priority order of services to be executed, in order to improve inspection techniques. Every inspection should be based on risk analysis, to keep its technical ground, so as not to jeopardize report and professional credibility. Risk analysis should determine the priority of services to be performed, eliminating any imminent danger to the building. It is expected, however, that the presented method may contribute to researches in the area of civil engineering, since the risk level classification works as a guideline for the interventions to be carried out by the manager in the building, ruling out any forthcoming risk to users [9].

\section{The Importance of Building Inspection}

Oliveira [10] believes that all professionals should be aware of the importance of building inspection, and the various necessary decisions on the complexity of a possible intervention. These decisions, to be taken by maintenance managers, should be based on the periodic inspection reports, so that a close inspection will identify performance issues and determine the degree of degradation of each component of the building system, aiming at analysing service priority. According to Bertolini [11], it is still important to note that each building component is affected differently by environmental aggressor agents as shown in Figs. 2-4. The inspection routine detects any degradation processes that can be treated early, allowing the life of the building project to be reached and even exceeded.

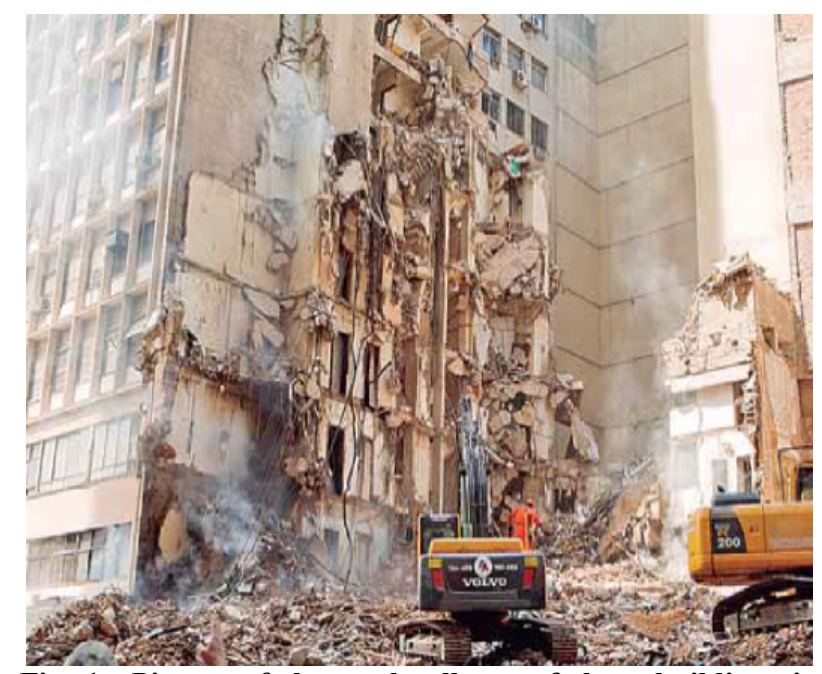

Fig. 1 Picture of the total collapse of three buildings in downtown Rio de Janeiro. 


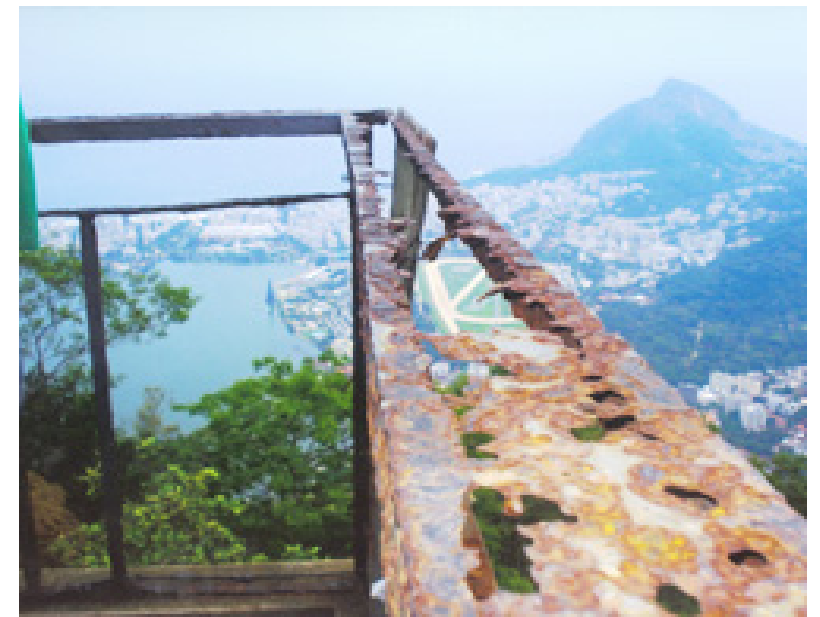

Fig. 2 The picture shows the corrosion on the guardrail structure.

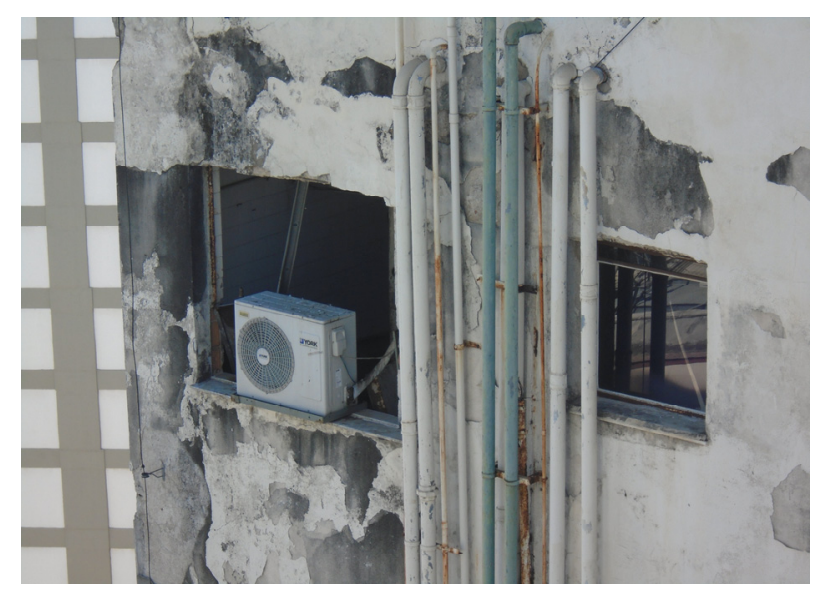

Fig. 3 The picture shows plaster detachment on façade.

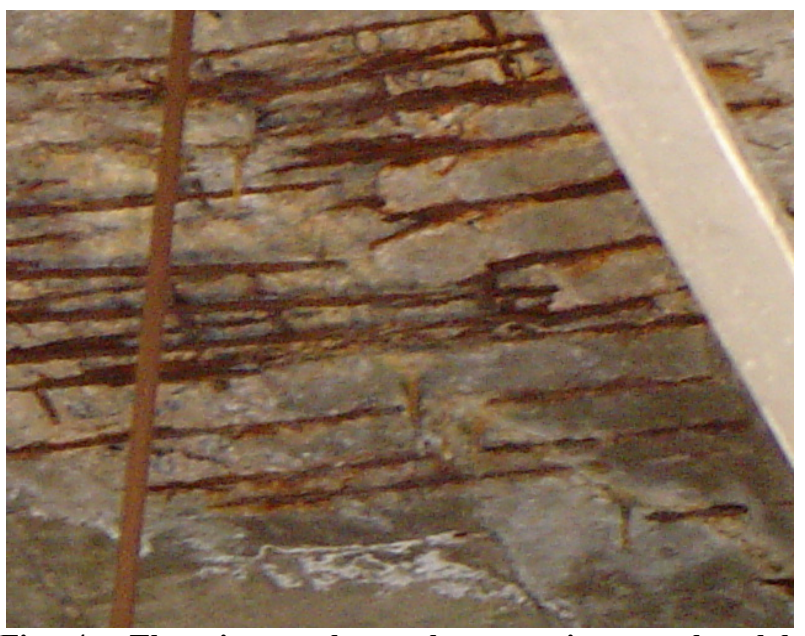

Fig. 4 The picture shows the corrosion on the slab hardware.

According to Oliveira [10], building inspection is rarely performed voluntarily and properly, due to the lack of awareness of the importance of such procedure and the aversion of increasing condominium fees. The only way to ensure that this essential activity is carried out is through a relevant legislation.

Building inspection should not be confused with building maintenance, but rather understood as a tool to prepare the building maintenance plan of a building. According to Fagundes [12], it is the best available tool for managers to organize the building maintenance plan. It is useful to assist the manager in the organization and fundraising of the building maintenance, and to help in the formalization and implementation of the maintenance master plan. Fagundes believes that the inspection works as a building check-up, helping managers to point out the priority order of interventions through the risk analysis method. The inspection classifies the identified problems according to the risk of health and safety taking into consideration the degree of urgency, providing subsidies for the development of the maintenance plan from the intervention priority setting.

The inspection routine should provide the managers with the necessary information so that they can develop their maintenance plan according to the order of services priorities. However, managers, in fact, only work on the recovery of anomalies, when building performance is lower than the minimum acceptable limit, fact that may compromise the building and the lives of users [13]. Oliveira [10] points out that changes of conduct in relation to building maintenance are cultural aspects, and are carried out in the long run. In fact, such behaviours will change only through law reinforcement.

\section{Risk Analysis Methodology, According to Mosler}

The article presents a qualitative methodology of risk analysis based on Mosler method. This is a potential risk management tool that tracks the evolution of risks. According to Oliveira [10], building inspection is rarely performed voluntarily 
and properly, due to the lack of the diagnosis of internal and external environments - the strengths and the weaknesses - allowing the projection of potential risks. It is a subjective method and, therefore, must be used when there is no available and reliable historical data that can be mathematically employed [9].

Risk analysis is nothing more than knowing the chances of a risk to happen. The method is the basis for the identification, analysis and evolution of factors that can influence the manifestation and realization of the threat, projecting the impact of each risk. Its application depends on the inspector experience, for it is up to him to assign the scoring function to evaluate the criteria used in the method, therefore, the result may vary depending on his expertise and professional knowledge.

The Mosler method has six risk rating criteria. The survey highlights them making a brief comment about each of them:

\subsection{Function Criterion " F",}

It projects the negative consequences or damage that may alter the main activity of the company.

\subsubsection{Function Criterion "S"}

This criterion assesses the impact of a fulfilled threat on the realty, in other words, to what extent the affected realty can be replaced.

\subsubsection{Function Criterion "P"}

It measures the disturbance and the psychological effects that a particular damage may cause damage to the occupants, the location and its appearance, once the risk becomes reality.

\subsubsection{Function Criterion "E"}

It measures the range and the extent that the physical damage may cause to the company or organization.

\subsubsection{Function Criterion "A"}

This criterion measures the possibility of harm or risk that is likely to happen, given the cyclical and physical characteristics of the company or organization.

\subsubsection{Function Criterion "V"}

It measures which will be the financial losses caused by the realization of the risk.

\subsection{Criteria and Scoring of the Mosler Method} Adapted to Inspection

Based on the criteria and scores of the Mosler methodology, the research presents the criteria and scoring adapted to building inspection, regarding the risk analysis relating to anomalies as shown in Table 1.

Table 1 Criteria and scoring adapted from the Mosler method.

\begin{tabular}{|c|c|c|}
\hline Criterion & Scale & Scoring \\
\hline & Imminent & 5 \\
\hline & Not acceptable & 4 \\
\hline \multirow[t]{5}{*}{ Function } & Moderate & 3 \\
\hline & Acceptable & 2 \\
\hline & Minimum & 1 \\
\hline & Imminent & 5 \\
\hline & Not acceptable & 4 \\
\hline \multirow[t]{5}{*}{ Substitution } & Moderate & 3 \\
\hline & Acceptable & 2 \\
\hline & Minimum & 1 \\
\hline & Imminent & 5 \\
\hline & Not acceptable & 4 \\
\hline \multirow[t]{5}{*}{ Depth } & Moderate & 3 \\
\hline & Acceptable & 2 \\
\hline & Minimum & 1 \\
\hline & Imminent & 5 \\
\hline & Not acceptable & 4 \\
\hline \multirow[t]{5}{*}{ Extension } & Moderate & 3 \\
\hline & Acceptable & 2 \\
\hline & Minimum & 1 \\
\hline & Imminent & 5 \\
\hline & Not acceptable & 4 \\
\hline \multirow[t]{5}{*}{ Aggression } & Moderate & 3 \\
\hline & Acceptable & 2 \\
\hline & Minimum & 1 \\
\hline & Imminent & 5 \\
\hline & Not Acceptable & 4 \\
\hline \multirow[t]{3}{*}{ Vulnerability } & Moderate & 3 \\
\hline & Acceptable & 2 \\
\hline & Minimum & 1 \\
\hline
\end{tabular}


Table 2 Risk analysis criteria.

\begin{tabular}{|c|c|c|}
\hline \multicolumn{3}{|l|}{ Risk analysis criteria } \\
\hline Function criteria & $\mathrm{F}$ & $\begin{array}{l}\text { Evaluates the imminent risks to the } \\
\text { building }\end{array}$ \\
\hline Substitution criteria & $\mathrm{S}$ & Evaluates the repair urgency \\
\hline Depth criteria & $\mathrm{P}$ & $\begin{array}{l}\text { Measures the damage effects on the } \\
\text { building }\end{array}$ \\
\hline Extension criteria & $\mathrm{E}$ & $\begin{array}{l}\text { Measures the damage extension in } \\
\text { the building }\end{array}$ \\
\hline Aggression criteria & A & $\begin{array}{l}\text { Evaluates the damage condition and } \\
\text { the risk of failure }\end{array}$ \\
\hline $\begin{array}{l}\text { Vulnerability } \\
\text { criteria }\end{array}$ & $\mathrm{V}$ & $\begin{array}{l}\text { Measures the adverse impacts to the } \\
\text { building in case of failure }\end{array}$ \\
\hline
\end{tabular}

Table 3 Tolerability criteria of risk.

\begin{tabular}{ll}
\hline Risk tolerability matrix & \\
\hline Risk scale & Scoring \\
\hline Imminent & 5 \\
Not acceptable & 4 \\
Moderate & 3 \\
Acceptable & 2 \\
Minimum & 1 \\
\hline
\end{tabular}

\subsection{Risk Analysis Criteria Adapted to Inspection}

As shown in Table 1, the Mosler Method has six risk analysis criteria. The research adapts these criteria having regard to inspection demands as demonstrated in Table 2:

\subsection{Tolerability Criteria of Risks adapted to Inspection}

Note that the following risk scale was created for each criterion that should be assessed under five aspects described in Table 3.

\subsection{The Mosler Method and the Risk} Evolution-Calculation Log

In the Mosler method, the risk classification is done by calculating an index called the risk evolution. The higher its value, the greater the risk posed to the organization. The risk valuation is calculated as follows.
The value is achieved by calculating a " $C$ " magnitude and quantifying its occurrence probability " $P b$ " which is the size of the threat:

$$
\text { Risk evolution: } R E=C \times P b
$$

In order to get to the quantification, it is necessary to calculate the risk magnitude $C$ :

$$
C=I+D
$$

where, $I$ : importance of success $F \times S$ (function $\times$ substitution); $D$ : damage caused $P \times E$ (depth $\times$ extension)

\subsection{Risk Magnitude}

The risk magnitude must be measured by the inspector. Thus, it requires an extensive knowledge in diagnostic engineering. The inspector must analyse the building pathology and grade the outcomes (1-5) according to the scale in Table 3 matching them with the criteria, $F / S / P / E / A / V$, presented in Table 2 .

$$
C=I(F \times S)+D(P \times E)
$$

Occurrence probability $P b$ :

$$
P b=A \times V \text { (aggression } \times \text { vulnerability) }
$$

The assigned values for $M, S, Q, E, A, V$, in Table 4 were obtained from Table 1, according to the professional technical assessment. With these values, it is possible to calculate $F \times S, P \times E, I+D, A \times V$, $C \times P b$. In the example of Table 4 , the value for $R E$ was 333 .

\subsection{Risk Evolution RE/Risk Classification}

According to Table 5, the value 333 for risk evolution $(R E)$ accounts for a small risk classification.

\section{Considerations}

The Mosler method has proven effective concerning the required safety considering the

\begin{tabular}{|c|c|c|c|c|c|c|c|c|c|c|c|}
\hline \multirow[t]{2}{*}{ Risk } & $F$ & $S$ & $P$ & $E$ & $A$ & V & $\begin{array}{l}(F \times S) \\
I\end{array}$ & $\begin{array}{l}(P \times E) \\
D\end{array}$ & $\begin{array}{l}(I+D) \\
C\end{array}$ & $\begin{array}{l}(A \times V) \\
P B\end{array}$ & $\begin{array}{l}(C \times P b) \\
R E\end{array}$ \\
\hline & 4 & 3 & 5 & 5 & 3 & 3 & 12 & 25 & 37 & 9 & 333 \\
\hline
\end{tabular}
available data sample and the inspector's technical knowledge.

Table 4 Calculation log-the Mosler method. 
Table 5 Risk evolution.

\begin{tabular}{ll}
\hline Risk evolution $R E$ & Risk classification \\
\hline $2 \sim 250$ & Very low \\
$251 \sim 500$ & Low \\
$501 \sim 750$ & Normal \\
$751 \sim 1,000$ & Big \\
$1,001 \sim 1,250$ & High \\
\hline
\end{tabular}

The findings were based on the literature review, using the most appropriate method for risk analysis within building inspection. Among the researched methods, the Mosler method showed better applicability to building inspection programs with risk analysis, since its functions criterion methodology allows the assessment of anomalies under six predefined aspects, by assigning degrees ranging on a scale from minimum risk (1) to imminent risk (5). Such variation not only defines the sample risk level, but also determines, at the end of the inspection, the priority order of service, which is based on the analysis result and the calculation chart presented in Section 5.8/5.9. It should be noted, however, that the inspector shall classify the anomalies based on his technical expertise. At the end of the assignment, the inspector should perform the calculation $\log$ of the inspected items to identify the priority order of service execution, once a broken tile cannot have the same importance as a fractured beam, for instance.

From then, the decision making concerning the correction of anomalies takes place, with the proper intervention priority order based on the presented imminent risk.

\section{Conclusions}

The article showed that building inspection is a fundamental tool for the elaboration of a building maintenance plan, which should be performed by qualified professionals who possess a systemic view of the building with an experience in building maintenance. The building maintenance preceded by inspection aims at preserving and increasing the useful life of the building, its elements and equipment, as well as the user safety. A working script is a basic procedure in any segment, and it should not be different when it comes to buildings maintenance.

The article presents a risk analysis methodology based on the Moser method and adapted by the authors for the use in building inspection. The research has shown the importance of developing a tolerability matrix of risk to be used during building inspection. Only a risk analysis of the inspected items can ensure the decision making on the necessary actions regarding the priority order of service execution to be determined by the inspector that will rule out any imminent risk to the building caused by negligence. The methodology should be applied during inspection in order to make the correct preparation of the building inspection report. This is a technical modeling methodology allows an individual analysis of each component involved in the building performance, enabling the adjustment and the introduction of building maintenance techniques aiming at the quality of the building. Moreover, the method may prove to be an important tool to assist in the elaboration of a building maintenance plan. The deliberation of the pathology degree of commitment based on risk analysis determines the priority order of interventions to be carried out based on a scale where 1 represents the optimal conditions of maneuverability in contrast to 5, which implies imminent danger to the building.

By this mean, the inspector is able to direct the manager about the range of services to be performed to avoid any error-related risks to the building regarding the prioritization of repair interventions, once a cracked brick should not have the same importance. A technical guidance error related to repair intervention priority to be performed in the 
building may represent irreparable risks to the building and, consequently to people's lives.

\section{References}

[1] Prata, H. 2004. Manual de Manutenção de Edificios-Guia Prático (Building Maintenance Manual-Practical Guide). 2nd ed. Porto: Publindústria. (in Portuguese)

[2] Cóias, V. 2009. Inspeção e Ensaios na Reabilitação de Edificios (Inspection and Testing in Building Rehabilitation). 3rd ed. Lisboa: IST (International Science and Technology Transactions) Press. (in Portuguese)

[3] Gomide, T. L. F., Fagundes Neto, J. C. P., and Gullo, M. A. 2011. Inspeção Predial Total: Diretrizes e Laudos no Enfoque da Qualidade Total e da Engenharia Diagnóstica (Total Building Inspection: Guidelines and Reports in Dealing with the Total Quality and Diagnostic Engineering). São Paulo: Pini. (in Portuguese)

[4] Lima, M. R. de C. 2007. "Impactos Econômicos do Estágio Atual da Cultura da Manutenção Predial no Brasil (Current Stage of Economic Impacts of Building Maintenance Culture in Brazil)." Presented at COBREAP - Congresso Brasileiro de Engenharia de Avaliações e Perícias, Salvador, November 5th to 9th, 2007. (in Portuguese)

[5] Noya, M., and Motta, A. L. T. S. 2012. "Modelo de Inspeção Predial-Ferramenta para a Manutenção do Patrimônio Construído (Model Building Inspection Tool for the Built Heritage Maintenance)." Dissertação de Mestrado em Engenharia Civil, Universidade Federal Fluminense. (in Portuguese)

[6] Associação Brasileira de Normas Técnicas. 2012. NBR 5674: Manutenção de Edificações-Procedimento
(Maintenance Buildings-Procedure). Rio de Janeiro. (in Portuguese)

[7] Associação Brasileira de Normas Técnicas. 2011. NBR 14037: Diretrizes para Elaboração de uso, Operação e Manutenção das Edificações-Requisitos para Elaboração e Apresentação dos Conteúdos (Guidelines for Use of Development, Operation and Maintenance of Buildings-Requirements for Preparation and Presentation of Content). Rio de Janeiro. (in Portuguese)

[8] Lessa, A. K. M. da C., and De Souza, H. L. 2010. Gestão da Manutenção Predial: Uma Aplicação Prática (Management of Building Maintenance: A Practical Application). 1st ed. Rio de Janeiro: Qualitymark. (in Portuguese)

[9] Brasiliano, Antonio Celso Ribeiro. 2003. Manual do Planejamento-Gestão de Riscos Corporativos (Planning Manual-Corporate Risk Management.). São Paulo: Editora Sicurezza. (in Portuguese)

[10] De Oliveira, S. P., Silva, F., and Da Luiz, C. P. 2008. "Discussão do Papel das leis de Inspeção como Suporte para a Adoção de Estratégias de Manutenção Preventiva (Discussion of the Role of Inspection Laws as Support for Preventive Maintenance Strategies Adoption).” Presented at Congresso Brasileiro do Concreto Ibracon. (in Portuguese)

[11] Bertolini, L. 2010. Materiais de Construção: Patologia, Reabilitação, Prevenção (Building Materials: Pathology, Rehabilitation, Prevention). São Paulo: Editora Oficina de Textos. (in Portuguese)

[12] Fagundes Neto, J. C. P. 2008. Perícias de Fachadas em Edificações: Pintura (Skills Building Facades:Painting). São Paulo: Universitária de Diretio. (in Portuguese)

[13] Dertsch, S. F. 2013. Perícias de Engenharia: A Apuração dos Fatos (Skills Engineering: Finding Facts). 2nd ed. São Paulo: Universitária de Direito. (in Portuguese) 